\title{
THE APPRAISAL ANALYSIS OF CHARACTER IN RESOLUTION PART OF THE OLD MAN AND THE SEA BY ERNEST HEMINGWAY
}

\author{
Kadek Sonia Piscayanti \\ Universitas Pendidikan Ganesha \\ Sonia.piscayanti@undiksha.ac.id
}

\begin{abstract}
This research aimed to analyze the character of Santiago in resolution part of the novel "The Old Man and The Sea" by Ernest Hemingway using SFL Appraisal Theory. From the data analysis, it was found that attitude (affect) and graduation (force) dominated the appraisal items in the resolution part of "The Old Man and The Sea". In total there were 34 appraisal items found. There were 11 appraisal items on affect found (29.72\%), 3 items on judgment (8.1\%), 1 item on appreciation (2.7\%), 5 items on engagement (13.5\%) and 17 items on graduation (45.94\%). Those expressions developed from character revelation through dialogue and narration on setting, and those difference marks significant importance of character's development in the resolution part. The character revelations found in the resolution part are: reflective, affectionate (caring and loving), humble, wise, realistic, and optimistic. This research showed the contribution of appraisal theory, especially attitude and graduation to develop a character in fiction, to be more exact, vivid, and naturally convincing. In the context of language teaching, the awareness of linguistics expression, language evaluations on meanings and values are relevant to be introduced from early to get better understanding of the language.
\end{abstract}

Keywords : character, character revelations, attitude, affect, judgement, appreciation, engagement, graduation

\section{INTRODUCTION}

The Old Man and The Sea (abbreviated as TOMS) is an epic and famous novel written by Ernest Hemingway. This novel is a short novel by Ernest Hemingway published in 1952, which was awarded Pulitzer Price in 1953 and Nobel Prize for Literature in 1954. This is considered as one of the best literature works in the $20^{\text {th }}$ century. It tells a heroic story about an old man and his journey to catch a fish in the sea where he had a fight not only with a big fish but also with the nature and himself. This novel presented many philosophical values that can be learned. The old man showed us much to learn, from the strength as a human and as a strength as an old man who fights against the sea, and himself. He proved that a journey of an old man does not mean useless, he proved to people around that he can still conquer the nature regardless his age and weak physical condition.

Literature is a device to express meaning and values, through which we can learn from. Literature is a verbal work of art that has purpose to educate, to entertain, to educate and to inspire. Literature is a powerful tool to value life in a rich, creative, engaging and elaborative ways. TOMS is the invention of Ernest Hemingway that deals not only with the 


\section{ELITAL, (ENGLISH IANGUAGE 'TEACHING, APPLIED LINGUIS'TICS \\ ANI) II'T'BRA'T'URE)}

Vol. 1 No. 2, 2020

Available online at https://jurnal.iainponorogo.ac.id/index.php/eltall

issue on heroism as the theme, but also with humanity as central theme. This work is one of the greatest works in literature, as it is born from experience. Josephs (1966: 52 in Vitacolonna (1989)) stated that the key method of Hemingway's writing is inventing from experience, in which the author does use his own experience and does invent from it. Once Hemingway wrote "If you have a story, it is not hard to tell. Maybe people won't believe it. But you can tell it straight and true. A writer, of course, has to make up stories for them to be rounded, and not flat like photographs. But he makes them up out of what he knows." (Baker, ed., 1981: 678 in Vitacolonna (1989)). From the sentence, it is confirmed that a story that is born from experience is the best one. From an experience, a writer should make up stories to be rounded and not flat. That is the best power of fiction. Fiction according to Kennedy (1983) comes from the Latin word "fictio", a shaping, a counterfaiting, is a name for stories not entirely factual, but at least partially shaped, made up, imagined.

Prose fiction is a literary work that focus on the development of character in a made-up and convincing chronological arrangement. To make it short, prose fiction is a made up story about character. It means that the prose fiction is building character through made up events in a made up settings. Novel is one of kinds of literature that is categorized under prose fiction. TOMS is categorized as a short novel.

Short novel has the same elements as novel, namely character, characterization, plot, setting, point of view, and moral values. Among those elements, character and plot are the two most important elements. Character is the subject of the story while plot is how the character runs the story through sequence of events. In this research, character is analyzed through resolution part using Appraisal theory. The novelty of this research is that appraisal theory used to identify linguistic expressions found in the character development of specific part in resolution that gives a significant contribution in strengthening the character to be more vivid, emotionally convincing and impressing. Resolution part is one of the most significant part in prose fiction that it gives new insights on how linguistic expressions in resolution part analyzed through appraisal framework can construct more vivid and naturally convincing character. Resolution part is the best part of literature that will mark the meaning, the values and the impression of the story.

Character development in narrative is revealed by many aspects, firstly by direct presentation and secondly by indirect presentation (Basuki, 1988). Direct presentation can be delivered through description and or by conversation. Meanwhile indirect presentation can be delivered through interior monologue, flow of thoughts and action. It is presented through sequences of moments in the story. The common sequence structure in literature is beginning, middle, and end. Resolution is the end of the structure. It gives more powerful impact towards the story. This research aims at focusing the analysis on the end structure because end structure among those three is considered to be the least structure that is rarely talked about. Meanwhile the significance of resolution is literature is very important. Resolution is a part where the power of literature anchored. This part is the last for the writer to explore the power of the words. That is the last that makes an overall impact of a story, whether the story is meaningful or not, whether it is valuable or not, and whether it is memorable is not depends on the power of resolution. Resolution also is the gate where 


\section{ELITAL, (ENGLISH IANGUAGE 'TEACHING, APPLIED LINGUIS'TICS \\ ANI) II'T'BRA'T'URE)}

Vol. 1 No. 2, 2020

Available online at https://jurnal.iainponorogo.ac.id/index.php/eltall

meanings happen in the audience's minds. Impression, emotions, feeling, statement of appreciation, come in this stage. The resolution part is the most powerful part of a literature. Meaning and values are refocused and reinterpreted here, as it is more developed and strongly structured.

Literature has a very deep meaning. We can analyze literature with many perspective, one of those is by analyzing the linguistics expression, through SFL. Systemic Functional Linguistics is the tool used to analyze linguistics expression. The analysis used Appraisal theory by Martin and White (2005). Appraisal is concerned about the interpersonal meaning of a language. In this research particularly we will focus on the aspect of attitude and graduation which mostly appear as the appraisal items used to describe character. According to Martin and White (2005:35), attitude is a framework of mapping feeling as they are construed in English texts. This system involves three semantic regions, namely emotion, ethics, and aesthetics. In this framework, they are named as affect, judgement, and appreciation. Engagement deals with sourcing attitudes and the play of voices around opinions in discourse. Meanwhile graduation attends to grading phenomena whereby feelings are amplified and categories blurred.

Attitude and graduations are mostly used here because it is a framework of mapping feelings as they are construed in English texts. Character is developed through sequence of events that lead to sequence of feelings. The tools to express emotions are linguistic expressions to represent emotions, feelings, setting and voice, psychological states of minds. In this analysis, we will discuss the aspects of attitude, engagement and graduation that are found in resolution part of the novel TOMS by Ernest Hemingway. The novelty of this research is that there are some appraisal items that are found in the resolution part of the novel build the new insight of how character is built through character revelation and setting.

\section{LITERATURE REVIEW}

\subsection{Situating Literature in SFL}

Prose fiction is a made up story about character. Character is defined as a subject of a story. Meanwhile characterization is the way how character is being represented. There are many kinds of character. First, main or major character. Second, minor character. Main character is the subject of the story while minor character is the supporting character that helps the plot to run logically. There are some ways of revealing character namely direct and indirect representation. Direct representation is the way the character is revealed through description or narration and dialogue. While indirect representation is the way a character being represented through description or narration, interior monologue, flow of thoughts, actions, and also dialogue. In this research, we will see how major character of Santiago is revealed through dialogue or conversation to present his character.

Character runs the story through plot. Plot is the arrangement of events in a story. It has structure namely beginning, middle and end. According to Basuki in the book Anatomy of Prose Fiction (1988), prose fiction has plot structure namely introduction, middle and 


\section{EL'TAL, (ENGLISH JANGUAGE' 'TEACHING, APPIIED) LINGUIS'IICS \\ ANI) II'T'BRA'T'URE)}

Vol. 1 No. 2, 2020

Available online at https://jurnal.iainponorogo.ac.id/index.php/eltall

end. In introduction, there are some aspects that are build, from the introduction of character, introduction of setting, introduction of problem. In the introduction of problem, it is introduced the points of attack that will lead to problem. In the middle part, the points of attack are developed through some stages namely crises, climax, and finally anticlimax. In the end part, the resolution, the points are meanings that are described through character, the problem solving, or the moments where character meets his/her final battle with the conflicts.

Literature research on character and character development in the context of SFL are many. First is by Khrisna, Djatmika, et.al (2020) found that character is developed through stages of orientation, complication, and resolution. In each stage the character is developed personally, emotionally, and physically. However, the gap I found is that there is no focus on character development in the resolution part. Therefore, this research is aimed at exploring the character development in the resolution part to meet the differences from orientation and complication stage. The focus of this research is to see how character is built through character revelation and setting in the resolution stage by using Appraisal theory.

Second one is by Horarik (2003) on his essay Appraisal and Narrative. In his research he found that narrative teaches through two kinds of subjectivity; intersubjectivity (a capacity to "feel with" a character) and supersubjectivity (a capacity to stand over a character and evaluate his or her action ethically). However in this research, I will try to see how character develops from both perspective of intersubjectivity and supersubjectivity because the appraisal theory used here needs a comprehensive look on the detailed description of character. It will see it as a linguistic expression and evaluated from many aspects of appraisal theory - from attitude, engagement and graduation. This is important to analyze all the items of appraisal, because their presence can not be ignored and because their presence is meaningful in character development.

This research, then will focus on how character is revealed through resolution part. The importance to see this because usually the character develops his manner gradually, and at the end the character will be stronger or more powerful than before after series of struggle in the story. The character's growth can be seen from the dialogue, the setting, and the narration. These aspects reveal the power of character. In this case, the character Santiago becomes stronger emotionally and psychologically after series of battle in his life. To see how the character is revealed in the resolution part, I will analyze the character through Appraisal Theory, on the aspects of attitude, engagement and graduation.

\subsection{Appraisal Theory}

According to Martin and White (2005), appraisal in SFL is the area of discourse semantic, to emphasize the meaning beyond the clause. It can be divided into three subsystem namely attitude, engagement and graduation. Attitude is the way feeling is expressed, including emotional reactions, judgements of behaviour, and evaluation of things. Engagement deals with sourcing attitude and the play of voices around opinion in 


\section{ELITAL, (ENGLISH IANGUAGE 'TEACHING, APPLIED LINGUIS'TICS \\ ANI) II'TIRA'TURE)}

Vol. 1 No. 2, 2020

Available online at https://jurnal.iainponorogo.ac.id/index.php/eltall

discourse. While graduation attends to grading phenomena whereby feelings are amplified and categories blurred.

Attitude can be divided into three categories; namely affect, judgement and appreciation. According to Martin and White (2005:42), affect is concerned with registering positive and negative feeling; judgement deals with attitude towards behaviour which we admire or criticize, praise or condemn; appreciation involves evaluations of semiotic and natural phenomena. Engagement deals with sourcing attitudes and the play of voices around opinion in discourse. While graduation attends to grading phenomena whereby feelings are amplified and categories blurred.

According to Li and Gao (2013), affect is the core of the attitude system, being either negative or positive, reflects the emotional responses and evaluation. Judgement explains the values that indicates how the appraiser, by reference to certain social norms and conventions or system of values, construct judgement toward human behaviour or activities. While appreciation is thing-oriented, involving the resources adopted to assess objects, processes and natural phenomena especially in aesthetic level.

Some appraisal analysis on literature have been widely researched. Some of them are by Macken-Horarik (2003) on Appraisal and the special instructiveness of narrative. This research considers the role of appraisal system in narrative discourse from the point of view writer/reader relations. It reveals the semantic attributes and analytical apparatus developed to contribute to creation of a text axiology in ideal readers. The research gives insight to explore more about the narrative discourse from the point of view writer/reader relations.

Li and Gao (2013) try to use Appraisal theory to analyze conflict discourse between mother and her daughter-in-law in the Novel Double-Sided Adhesive through attitudinal meanings. They found that affect and judgement appear mostly in the novel. This research gives deep understanding on the analysis of attitudinal meanings through affect and judgment. In relation to this research, it can give a comparison on how conflict is analyzed especially in the development of character in the story.

Khrisna, Djatmika, et.al (2018) found that character is developed through stages of orientation, complication, and resolution. The evaluation was focused on the character's emotion, personality and physical condition. By using appraisal theory the character can be analyzed as developed gradually in each stage. But here in this context, there is lacking of specific development of character in the resolution stage. This is where the gap I found, and will be analyzed more here.

Another appraisal analysis was done by Li (2016) through which attitudinal aspects of English song shows the importance of appraisal theory to build interpersonal relation between the author and the song. To put in context, it can be learned that interpersonal relation also built between author and the novel. 


\section{EL'TAL, (ENGLISH JANGUAGE' 'TEACHING, APPIIED) LINGUIS'IICS ANI) II'TIRA'TURE) \\ Vol. 1 No. 2, 2020 \\ Available online at https://jurnal.iainponorogo.ac.id/index.php/eltall}

Another research was done on appraisal theory about the commentary of Ernest Hemingways' A Farewell to Arms by using the analytical tool of attitude, engagement and graduation system. To put in this context, I also used the analytical tool of attitude, engagement and graduation.

After reviewing some research, I found that the character development viewed from appraisal theory is still few especially in the context of resolution. Character is developed not only by the character revelation by dialogue but also through setting and narration. The analysis of character in novel on appraisal items especially in resolution is the novelty of this research.

\section{RESEARCH METHODS}

The method of this research is descriptive qualitative in which it uses description to describe the linguistics expression. The design used is content analysis. Content analysis is a systematic research method for analyzing and making inferences from text. The primary data is the text of The Old Man and The Sea by Ernest Hemingway especially on the resolution part. The analysis used appraisal theory by Martin and White (2005).

\section{RESULTS AND DISCUSSION}

4.1 The result of the analysis can be seen in the following table.

Table 4.1 Appraisal Analysis of character in The Old Man and The Sea

\begin{tabular}{|l|l|l|l|l|l|l|l|}
\hline $\begin{array}{l}\text { Appraisin } \\
\text { g items }\end{array}$ & Appraiser & Affect & $\begin{array}{l}\text { Judge } \\
\text { ment }\end{array}$ & $\begin{array}{l}\text { Appreciati } \\
\text { on }\end{array}$ & $\begin{array}{l}\text { Engagem } \\
\text { ent }\end{array}$ & $\begin{array}{l}\text { Graduat } \\
\text { ion }\end{array}$ & Appraised \\
\hline beat me & Santiago" & $\begin{array}{l}\text { neg } \\
\text { +hap }\end{array}$ & & & & Manolin \\
\hline truly beat & Santiago" & & & & $\begin{array}{l}\text { Force: } \\
\text { intensific } \\
\text { ation } \\
\text { (process } \\
\text { ) }\end{array}$ & Manolin \\
\hline Truly & Santiago" & & & & $\begin{array}{l}\text { Force: } \\
\text { intensific } \\
\text { ation } \\
\text { (quality) }\end{array}$ & Manolin \\
\hline didn't beat & Manolin & & & & $\begin{array}{l}\text { Heteroglo } \\
\text { ss: } \\
\text { dquantiago } \\
\text { disclaim/ } \\
\text { deny }\end{array}$ & & Santiago \\
\hline do you & & & & & & & \\
\hline
\end{tabular}




\section{BL'TALL (ENGLISH IANGUAGE 'TEACHING, APPLIEI) LINGUISTIICS}

ANI) II'TIRA'TURE)

Vol. 1 No. 2, 2020

Available online at https://jurnal.iainponorogo.ac.id/index.php/eltall

\begin{tabular}{|c|c|c|c|c|c|c|c|}
\hline want & & & & & & & \\
\hline you want & Santiago" & + des & & & & & Manolin \\
\hline I want & Manolin" & + des & & & & & Santiago \\
\hline very big & Santiago" & & & & & $\begin{array}{l}\text { Force:qu } \\
\text { antificati } \\
\text { on of } \\
\text { mass }\end{array}$ & sea \\
\hline small & Santiago" & & & & & $\begin{array}{l}\text { Force:qu } \\
\text { antificati } \\
\text { on of } \\
\text { mass }\end{array}$ & skiff \\
\hline hard to see & Santiago" & & & & & $\begin{array}{l}\text { Force:qu } \\
\text { antificati } \\
\text { on of } \\
\text { mass }\end{array}$ & skiff \\
\hline $\begin{array}{l}\text { I missed } \\
\text { you }\end{array}$ & Santiago" & +hap & & & & & Manolin \\
\hline very good & Santiago" & & & pos +reac & & & Manolin \\
\hline not lucky & Santiago" & & -norm & & & & Manolin \\
\hline $\begin{array}{l}\text { not lucky } \\
\text { anymore }\end{array}$ & Santiago" & & & & & $\begin{array}{l}\text { Force:int } \\
\text { ensificati } \\
\text { on via } \\
\text { repetitio } \\
\mathrm{n}\end{array}$ & Manolin \\
\hline The hell & Manolin" & $\begin{array}{l}\text { neg } \\
\text { +hap }\end{array}$ & & & & & luck \\
\hline do not care & Manolin" & & & & $\begin{array}{l}\text { Heteroglo } \\
\text { ss:contrac } \\
\mathrm{t} \\
\text { disclaim- } \\
\text { deny }\end{array}$ & & $\begin{array}{l}\text { Manolin's } \\
\text { family }\end{array}$ \\
\hline $\begin{array}{l}\text { much to } \\
\text { learn }\end{array}$ & Manolin" & & & & & $\begin{array}{l}\text { Force: } \\
\text { quantific } \\
\text { ation } \\
\text { mass/pr } \\
\text { esence }\end{array}$ & Santiago \\
\hline get a good & Santiago" & & + prop & & & & Manolin \\
\hline $\begin{array}{l}\text { always } \\
\text { have }\end{array}$ & Santiago" & & & & & $\begin{array}{l}\text { Force : } \\
\text { intensific } \\
\text { ation- } \\
\text { modality }\end{array}$ & The knife \\
\hline heavy brisa & Santiago" & & & & & $\begin{array}{l}\text { Force : } \\
\text { quantific } \\
\text { ation } \\
\text { (mass) }\end{array}$ & sea \\
\hline
\end{tabular}




\section{BL'TAL, (ENGLISH JANGUAGE' 'TEACHING, APPIIID) LINGUIS'TICS ANI) II'T'BRA'T'URE)}

Vol. 1 No. 2, 2020

Available online at https://jurnal.iainponorogo.ac.id/index.php/eltall

\begin{tabular}{|c|c|c|c|c|c|c|}
\hline $\begin{array}{l}\text { Maybe } \\
\text { three. } \\
\text { Maybe } \\
\text { more }\end{array}$ & Manolin" & & & $\begin{array}{l}\text { Heteroglo } \\
\text { ss } \\
\text { Entertain } \\
\text { dialogistis } \\
\text { tic } \\
\text { expansive } \\
\text { ness }\end{array}$ & & heavy brisa \\
\hline Old man & Manolin" & & $+\mathrm{val}$ & & & Santiago \\
\hline $\begin{array}{l}\text { something } \\
\text { strange }\end{array}$ & Santiago" & -sec & & & & chest \\
\hline was broken & Santiago" & - sec & & & & chest \\
\hline plenty & Santiago" & & & & $\begin{array}{l}\text { Force: } \\
\text { intensific } \\
\text { ation } \\
\text { (mass) }\end{array}$ & Manolin \\
\hline $\begin{array}{l}\text { he was } \\
\text { crying }\end{array}$ & narrator & -hap & & & & Santiago \\
\hline $\begin{array}{l}\text { empty beer } \\
\text { cans }\end{array}$ & narrator & & & & $\begin{array}{l}\text { Force : } \\
\text { intensific } \\
\text { ation } \\
\text { (mass) }\end{array}$ & beach \\
\hline $\begin{array}{l}\text { dead } \\
\text { barracudas }\end{array}$ & narrator & & & & $\begin{array}{l}\text { Force : } \\
\text { intensific } \\
\text { ation } \\
\text { (mass) }\end{array}$ & water \\
\hline a great long & narrator & & & & $\begin{array}{l}\text { Force } \\
\text { :intensifi } \\
\text { cation } \\
\text { (mass) }\end{array}$ & fish \\
\hline a huge tail & narrator & & & & $\begin{array}{l}\text { Force: } \\
\text { intensific } \\
\text { ation } \\
\text { (mass) }\end{array}$ & fish \\
\hline $\begin{array}{l}\text { heavy } \\
\text { steady sea }\end{array}$ & narrator & & & & $\begin{array}{l}\text { Force } \\
\text { :intensifi } \\
\text { cation } \\
\text { (mass) }\end{array}$ & sea \\
\hline great fish & narrator & & & & $\begin{array}{l}\text { Force } \\
\text { :intensifi } \\
\text { cation } \\
\text { (mass) }\end{array}$ & fish \\
\hline $\begin{array}{l}\text { didn't } \\
\text { know }\end{array}$ & people & & & $\begin{array}{l}\text { Heteroglo } \\
\text { ss:contrac } \\
\text { t } \\
\text { disclaim- }\end{array}$ & & Shark \\
\hline
\end{tabular}




\section{BL'TALL (BNGLISH IANGUAGE 'TEACHING, APPLIED LINGUIS'TICS ANI) LI'T'BRA'TURE) \\ Vol. 1 No. 2, 2020 \\ Available online at https://jurnal.iainponorogo.ac.id/index.php/eltall}

\begin{tabular}{|c|c|c|c|c|c|c|c|}
\hline & & & & & deny & & \\
\hline $\begin{array}{l}\text { Handsome, } \\
\text { beautifully } \\
\text { formed }\end{array}$ & & & & & & $\begin{array}{l}\text { Force : } \\
\text { quantific } \\
\text { ation } \\
\text { (mass) }\end{array}$ & \\
\hline $\begin{array}{l}\text { didn't } \\
\text { know } \\
\text { either }\end{array}$ & & & & & $\begin{array}{l}\text { Heteroglo } \\
\text { ss:contrac } \\
\mathrm{t} \\
\text { disclaim- } \\
\text { deny }\end{array}$ & & \\
\hline $\begin{array}{l}\text { was } \\
\text { dreaming }\end{array}$ & narrator & +hap & & & & & $\begin{array}{l}\text { The old } \\
\text { man }\end{array}$ \\
\hline The lions & narrator & +hap & & & & & $\begin{array}{l}\text { The old } \\
\text { man }\end{array}$ \\
\hline \multicolumn{2}{|l|}{ Total items } & 11 & 3 & 1 & 5 & 17 & \\
\hline
\end{tabular}

From the table above we can summarize the result of the appraisal items found as follows.

Table 4.1.1 The Summary Result of Appraisal Items

\begin{tabular}{|l|l|l|}
\hline Appraisal items & Number of items & Percentage \\
\hline Affect & 11 & $29.72 \%$ \\
\hline Judgement & 3 & $8.1 \%$ \\
\hline Appreciation & 1 & $2.7 \%$ \\
\hline Engagement & 5 & $13.5 \%$ \\
\hline Graduation & 17 & $45.94 \%$ \\
\hline Total & 37 & $100 \%$ \\
\hline
\end{tabular}

From the table we can see that attitude aspects found are;

\subsection{Discussion}

\subsubsection{Discussion on each Appraisal Items}

The discussion on each appraisal items from the table above can be explained as follows. Here I used bold to mark the findings on attitude (affect, judgement, and appreciation), italics to mark the findings on engagement, and underline to mark the findings on graduation.

[4.2.1] They beat me, Manolin.

The expression is categorized as affect because it expresses the emotion of Santiago who was beaten by the fish. He is the appraiser to the appraised Manolin. This is taken from the direct speech of Santiago while he explained about the fight he had with the big 


\section{EL'TAL, (ENGLISH JANGUAGE' 'TEACHING, APPIIED) LINGUIS'IICS ANI) LI'TIRA'TURE) \\ Vol. 1 No. 2, 2020 \\ Available online at https://jurnal.iainponorogo.ac.id/index.php/eltall}

fish. The mark using double quotes for the indication that the appraiser was in a speech (following Halliday 1994). The emotion that was captured is a bit sad and low. According to Martin and White (2005:42) affect is concerned with registering positive and negative feeling and the expression above portrayed Santiago's feeling of a bit sad and unhappy. Thus it is categorized as negative +happiness or unhappiness.

[4.2.2] They truly beat me.

The expression is categorized as graduation on the type of force (intensification) as process. beat gives an intensification of the process of verb beat which means very intensely felt as a hard beat. It shows more on the process of the verb beat instead of only beat, but truly beat.

\section{[4.2.3] Truly}

The expression gives an intensification of the quality. It is different from the intensification of process. Truly here means the quality of the beat is really big. The intensity here is more powerful. This is to show how hard the fish fought Santiago in the ocean and that the fish was a strong and powerful enemy to Santiago.

[4.2.4] He didn't beat you.

The expression is categorized as engagement (disclaim) and deny. According to Martin and White (2005:97) disclaim is the textual voice which positions itself as at odds with, or rejecting, some contrary position. This expression is delivered by Manolin as appraiser to Santiago. He denied the fact that Santiago was beaten by the fish because Santiago is his role model as a fisherman. He denied the fact that Santiago lost the battle with the huge fish because he understood that Santiago is a special man who can conquer the fish and the sea.

\section{[4.2.5] What do you want done with the head?}

The expression is categorized as positive affect (desire). Since the appraiser Santiago asked sincerely to Manolin the question. Santiago feels emotionally positive about the head of the fish he had fought for. Head is the symbol of the major success in conquering the fish. If the fish is done, the head is the biggest price for the winning symbol. But here Santiago feels that he gives the power to decide for Manolin to do something with the head.

[4.2.6] You keep it if you want it.

The expression is categorized as positive affect (desire). This is to show that the appraiser Santiago want to give Manolin the best thing as the head of the fish because he deserved it. Manolin is a young boy who appraised Santiago as his teacher in the sea. Santiago feels positive to give Manolin the best part of the fish.

\section{[4.2.7] I want it.}

The expression is categorized as positive affect (desire). It shows that Manolin really wants the head of the fish. This is to support Santiago's effort to have such a big battle with the fish, and because their relationship is more than just friends, the exchange of positive emotion is shared between them. Santiago feels that Manolin is more than just a young boy but a best friend.

[4.2.8] The ocean is very big

The expression is categorized as graduation on the type of intensification (quality). Santiago is the appraiser who was trying to convince Manolin (appraised) that he is 


\section{EL'TAL, (ENGLISH JANGUAGE' 'TEACHING, APPIIED) LINGUIS'IICS ANI) LI'T'BRA'TURE) \\ Vol. 1 No. 2, 2020 \\ Available online at https://jurnal.iainponorogo.ac.id/index.php/eltall}

amazed at the ocean (the universe) as opposed to his small power as human. The ocean is the symbol of how big universe is compared to human.

[4.2.9] and a skiff is small and hard to see

The expression is small is categorized as graduation intensification (quality). Santiago is the appraiser who was making a comparison between the ocean and the skiff. He said that the ocean is very big and a skiff is small and hard to see. Here skiff (a small boat) is compared to ocean. Ocean is the symbol of universe while skiff is the symbol of human.

[4.2.10] hard to see

The expression hard to see is categorized as graduation intensification (quality). Santiago is the appraiser who was making a comparison between ocean (universe) and human (skiff) through the intensification of quality, that the ocean is very powerful and unlimited while human (skiff) is too small and nothing which is symbolized through expression very hard to see. Santiago is humbled by the power of universe as opposed to his power.

[4.2.11] I missed you

The expression I missed you is categorized as positive affect. Santiago is the appraiser to appraise Manolin in a positive emotion. He really missed Manolin in the sea when he had a big battle with the huge fish and hoping Manolin was there with him to help.

\section{[4.2.12] Very good}

The expression is categorized as appreciation. The types of appreciation is reaction on quality (Martin and White, 2005:56). This is the reaction by Santiago when Manolin said that he caught fish. It is an encouragement and reinforcement by Santiago to support Manolin. According to Martin and White (2005:57) reaction is related to affection (emotive) which has interpersonal metafunction. To Santiago, Manolin is not only a friend but a soulmate in the sea. So his achievement is seen as a big progress and he celebrated it by saying appreciation with supporting words.

[4.2.13] Not lucky

The expression is categorized as negative judgement on the type of social esteem. Martin and White (2005:53) categorized social esteem into three categories namely normality, capacity, and tenacity. Unlucky here belongs to negative social esteem (criticise) in which Santiago as appraiser thought that he is not a lucky person.

[4.2.14] Not lucky anymore

The expression is categorized as graduation on the type of intensification via repetition. According to Martin (2005:148) the intensification can be realized through repetition. It is called semantic infusion in the category of non-figurative.

\section{[4.2.15] The hell}

The expression is categorized as interjection which according to Jordens 2002 (in Martin and White, 2005:69) it is a particular types of swearing and other exclamations that maybe associated with particular types of attitude. In this context, I categorized this as affect negative +hap, because it represents unhappiness state of Manolin with the so-called luck. He did not trust luck as it is as a sign that he is not happy with just being lucky.

\section{[4.2.16] do not care}

The expression is categorized as engagement (disclaim) and deny. According to Martin and White (2005:97) disclaim is the textual voice which positions itself as at odds with, or rejecting, some contrary position. This expression is delivered by Manolin as appraiser to react to Santiago on his family. This happened when Santiago asked whether Manolin was 


\section{BL'TALL (ENGLISH IANGUAGE' 'TEACHING, APPIIED) LINGUIS'IICS \\ AND II'TIRA'TURE)}

Vol. 1 No. 2, 2020

Available online at https://jurnal.iainponorogo.ac.id/index.php/eltall

allowed to fish with him. Manolin's response about his family's concern on fishing with Santiago is a denial. He denied the fact that he must obey his family for not going with Santiago.

\section{[4.2.17] much to learn}

The expression is categorized as graduation type force sub type quantification on mass/presence. Much here represents Manolin's respect to Santiago's skills from which he can learn much from. Much is the quantification of mass. Much means uncountable mass. It means a lot. Here Manolin represented that he can learn a lot of knowledge on fishing from Santiago.

\section{[4.2.18] get a good}

The expression is categorized as judgements of propriety in the subtype of propriety of positive social sanction (Martin and White, 2005:53). This appraisal is delivered by Santiago to Manolin. This is to show that Santiago cares a lot about Manolin and he demanded Manolin to get a good killing lance that will teach Manolin again how to fish in the ocean with good preparation.

\section{[4.2.19] always}

The expression is categorized as graduation within infused intensification. According to Martin and White (2005:143) with infused intensification there is no separate lexical form conveying the sense of up-scaling or down-scaling. Rather the scaling is conveyed as but one aspect of the meaning of a single term. It is under the subtype of modality. To put in context, Santiago suggested Manolin to have prepared everything in need for a good fishing such as a good killing lance.

\section{[4.2.20] heavy brisa}

The expression is categorized as force quantification in the sub-type of mass (presence). According to Martin and White (2005:148) quantification involves scaling with respect to extent of size, weight, strength, number. Heavy brisa represents the sea winds that strongly blew when Santiago was in the ocean.

\section{[4.2.21] Maybe three. Maybe more.}

The expression is categorized as graduation on the type of heteroglossia within the subtype of the dialogistic expansiveness of modality. This is to emphasize that Manolin was not sure how many days that brisa happened. Modality here means that it is a possibility of uncertainty. According to Martin and White (2005:107) the modality is a sign that the appraiser's knowledge of the matter (brisa) is to some degree limited.

\section{[4.2.22] old man}

The expression is categorized as appreciation, within type of positive valuation. This is to represent that Manolin value and appreciate Santiago as positive role model.

Manolin considers Santiago as his teacher so keeping Santiago safe is his duty. This is why Manolin tries to make Santiago feels secured by appraising him with positive appreciation.

\section{[4.2.23] Something strange}

The expression is categorized as affect since it produces feeling or emotions. It is a type of negative security. In which here Santiago as appraiser feels insecure about his condition. 


\section{ELITAL, (ENGLISH IANGUAGE 'TEACHING, APPLIED LINGUIS'TICS \\ ANI) II'TIRA'TURE)}

Vol. 1 No. 2, 2020

Available online at https://jurnal.iainponorogo.ac.id/index.php/eltall

\section{[4.2.24] was broken}

The expression is categorized as affect since it produces feeling or emotions. It is a type of negative security. In which Santiago feels insecure about his chest after being beaten by the huge fish.

\section{[4.2.25] Plenty}

The expression is categorized as graduation on the type of force under the type of subtype of intensification of mass. This means that the appraiser Santiago wants to put emphasis that he suffered a lot. Plenty means a lot.

\section{[4.2.26] he was crying}

The expression is categorized as affect on the type of negative happiness. This is because Manolin feels sad about Santiago and his condition.

[4.2.27] empty beer cans

The expression is categorized as graduation on the type of intensification (quality). The setting with focus on the situation around the beach strengthens the feeling of Santiago and his emotions.

[4.2.28] dead barracudas

The expression is categorized as graduation on the type of intensification (quality). The setting represents the atmosphere of silence and sadness.

[4.2.29] A great long

The expression is categorized is categorized as force quantification in the sub-type of mass (presence). This is to represent the size which is very long since it is the biggest fish ever in the context of Santiago's journey.

\section{[4.2.30] A huge tail}

The expression is categorized as force quantification in the sub-type of mass (presence). This is to represent that the fish's tail is very big. It is the biggest fish in the context of the story, a shark or called Tiburon.

\section{[4.2.31] Heavy steady}

The expression is categorized as force quantification in the sub-type of mass (presence). Heavy steady refers to the sea.

\section{[4.2.32] Great fish}

The expression is categorized as force quantification in the sub-type of mass (presence). This is to represent the magnificent power of the fish that Santiago fought. It is not an ordinary fish but indeed a great fish who faced a great human (Santiago).

\section{[4.2.33] didn't know}

The expression is categorized as engagement (disclaim) and deny. The people in the story as appraiser showed their amazed feeling at the huge fish that they never know existed before.

\section{[4.2.34] handsome beautifully formed}

The expression is categorized as graduation on the type of intensification (quality). This is to show how beautiful the huge creature is and how amazed they are at seeing the handsome animal. 


\section{BLT'ALL (ENGLISH LANGUAGE 'TEACHING, APPLIII) LINGUISTIICS}

ANI) LI'TRRA'U'URE)

Vol. 1 No. 2, 2020

Available online at https://jurnal.iainponorogo.ac.id/index.php/eltall

\section{[4.2.35] didn't know either}

The expression is categorized as engagement (disclaim) and deny. This is to show that no people in the context of the story have noticed or have known the creature before in their entire life.

[4.2.36] Was dreaming

The expression is categorized as positive affect (desire). This represents the peace falls upon Santiago who has won a battle of life and death with universe (the sea and the giant fish).

[4.2.37] The lions

The expression is categorized as positive affect (desire). The lions are representation of the king of animal which could be the symbol that Santiago has reached his final goal as human.

\subsection{CHARACTER DEVELOPMENT OF SANTIAGO}

To discuss the character development of Santiago, I will describe the character development as follows. I will show the analysis of how character Santiago develops through resolution part with the discussion of findings above

\subsubsection{Reflective character}

First, Santiago is more reflective. He undergoes series of battles with the nature and therefore he becomes more reflective and respective to nature. That he can not beat the nature. The phase "ocean is very big" represent Santiago's respect to nature. It can be seen in the discussion above point [4.2.8] on the appraisal item very big which belongs to graduation (subtype of quantification-mass). Ocean is symbolized here as universe that ocean is capable of doing everything, because it is a nature that owns the power. However, as we can see on the point of [4.2.9] "and a skiff is small and hard to see" belongs to graduation on subtype of quantification-mass in which Santiago reflects as if a skiff is a human capacity that is not capable to fight the nature. Skiff is a boat that can easily be played by the mighty ocean who owns the power. Santiago reflects on the human capacity that compares nothing to nature. The graduation of appraisal is used here to compare and contrast the quantity of power between the nature and the human. In this resolution, Santiago is more reflective due to his battle with the fish and the ocean. He becomes more aware of his own limit as an old man.

\subsubsection{Affectionate, caring and loving character}

Santiago shows more affectionate, caring and loving It can be seen from the clause "I missed you." As can be seen in the discussion of finding above point [4.2.11], I categorized this as a positive affect because it raises the positive and warm feeling to other character, Manolin. Manolin has been the old man's best friend, a young man that learns a lot from Santiago. This clause is a proof that Santiago respects the young man and that the young man deserved to be respected. It can also be seen from the the expression used that shows how close they are. In the resolution part, the character reveals even stronger power of 


\section{EL'TAL, (ENGLISH JANGUAGE' 'TEACHING, APPIIED) LINGUIS'IICS ANI) LI'TIRA'TURE) \\ Vol. 1 No. 2, 2020 \\ Available online at https://jurnal.iainponorogo.ac.id/index.php/eltall}

intimacy between Santiago and Manolin. In the beginning and middle part, this relationship do not reveal much. But here, in resolution part, it gives us clearer picture of SantiagoManolin's relationship. This shows that Santiago cares about Manolin so much. He showed that he supports Manolin in such a way. This is also supported by the expression "very good". In the discussion point of [4.2.12] "Very good" belongs to positive appreciation in the form of "reaction". Reaction category here based on the quality whether the appraiser like it or not. Here, Santiago seems to like it very much. When Santiago says "very good", he shows that he likes what Manolin does. He reacts positively towards Manolin.

Another proof is the point of [4.2.5] and [4.2.6] which show positive affect from Santiago to Manolin. The expressions show that Santiago cares about Manolin so much is expressed through "what do you want done with the head?" and that he is willing to give the best part of the fish for Manolin by saying "You keep it if you want it."

\subsubsection{Humble character}

Third, Santiago is more humble. It can be seen from the expression, "No, I am not lucky." According to Martin and White (2005:53) it belongs to negative judgement on the type of social esteem, on substype of normality (criticise). As can be seen in the point of discussion [4.2.13] "I am not lucky" refers to his feeling about his own self-esteem, that he is not lucky or he does not have the luck to be able to handle hard situation. He is humbled more. This also supported by the next expression "I am not lucky anymore". In the discussion point [4.2.14] shows that it belongs to graduation on the types of intensification via repetition. The power of graduation via repetition here gives more emphasis on how Santiago feels more humbled. He feels that he is not as lucky as usual (he used to be lucky) so he said "I am not lucky anymore" to intensify his feeling.

\subsubsection{Wise character}

The fourth, Santiago is wise. It could be seen from the clause "we must get a good killing lance" that belongs to positive judgement on social sanction on the subtype of propriety as discussed in point [4.2.18]. It shows that Santiago is wiser to handle the situation after the experience he had. He wanted to be more ready and steady for any possibilities. It is also supported by the next expression "and always have it on board". The discussion can be found in point [4.219] that belongs to graduation within infused intensification on the subtype of modality. This graduation type put bigger power of emphasis to show that Santiago is much more anticipating and risk-taking. "Always" refers to the readiness on each situation.

\subsubsection{Realistic character}

Santiago is realistic and honest as can be seen in the point [4.2.23] which says in the expression "In the night I spat something strange" in which it belongs to negative affect insecurity. Here Santiago is realistic and honest about his feeling that he feels insecure about his condition. This is also supported by the point [4.2.24] on the expression "was broken".The expression is categorized as affect since it produces feeling or emotions. In 


\section{BL'TALL (ENGLISH JANGUAGE 'TEACHING, APPLIEI) LINGUIS'TICS}

ANID LI'TRRA'URE)

Vol. 1 No. 2, 2020

Available online at https://jurnal.iainponorogo.ac.id/index.php/eltall

which Santiago feels insecure about his chest after being beaten by the huge fish. He is realistic about his physical condition. Another support is shown in the point [4.2.25] "Plenty". The expression is categorized as graduation on the type of force under the type of subtype of intensification of mass. He is realistic that he suffered a lot.

\subsubsection{Optimistic character}

The optimistic character of Santiago can be seen in the last part of the resolution that he was dreaming of the lions. It can be found in the point [4.2.36] on the expression "Was dreaming". The expression is categorized as positive affect (desire). This represents the peace falls upon Santiago who has won a battle of life and death with universe (the sea and the giant fish). It is supported by the point [4.2.37] on the expression of "The lions". The expression is categorized as positive affect (desire). The lions are representation of the king of animal which could be the symbol that Santiago has reached his final goal as human. Santiago has shown not only to himself but also to other people that he is the strong and powerful fisherman as he could fight a shark by himself.

\subsection{THE CONTRIBUTION OF APPRAISAL ON CHARACTER DEVELOPMENT}

The contribution of Appraisal in the context of character development in literature is as follows.

First, it gives clear and vivid picture of character in terms of physical appearance. By the use of narration, dialogue, and description, character can be revealed thoroughly. The role of appraisal here especially graduation is to give emphasis on the quality and quantity of things that empower the character development. According to Basuki (1988) character develops through narration and description to give real picture of character and convincing character.

Second, it gives clear and emotional picture of character in terms of psychological state of mind. The role of affect and judgement is very significant to build a strong emotional and psychological "picture" of a character. Without attitude aspects such as affect, judgement, and appreciation, the emotional state of characters' mind can not be delivered clearly. It is also the power of engagement and to give more emphasis on the real mind state of the character. As found by Khrisna, Djatmika, et.al (2020) that character is developed through stages of orientation, complication, and resolution. In each stage the character is developed personally, emotionally, and physically. Here the contribution of appraisal theory is very significant.

Last but not least, this contribution of appraisal goes along with findings by MackenHorarik (2003) which found that character develops from both perspective of intersubjectivity and supersubjectivity. In this context, both are used in this analysis because the appraisal theory can be found in both ways and contribute significantly in this study. Intersubjectivity is the feeling to think from the character's mind and supersubjectivity is the capacity to feel the character from outside as to evaluate it objectively. 


\section{BL'TALL (ENGLISH JANGUAGE 'TEACHING, APPLIEI) LINGUIS'TICS}

ANID LI'TRRA'URE)

Vol. 1 No. 2, 2020

Available online at https://jurnal.iainponorogo.ac.id/index.php/eltall

\subsection{THE CONTRIBUTION OF APPRAISAL ON LANGUAGE TEACHING}

The contribution of appraisal theoruy on language teaching are as follows.

First, it builds stronger awareness of language and the appropriate use of language in its context. In language teaching this is significant to train students to apply different language in different discourse as to rehearse language sensititivity.

Second, it builds language confidence and sensitivity as the knowledge on appraisal will sharpen, deepen, and widen the perspective of the language.

\section{CONCLUSION}

It can be concluded that the appraisal is significant in literature especially in character development because it uses every aspects of appraisal including attitude, engagement and graduation to evaluate the language in literature context. This study on appraisal analysis on literature can open more discourse and more possibility to stimulate further research on similar theme.

\section{REFERENCES}

Dong, T., \& Lin, X. (2018). Attitude in appraisal theory: a comparative analysis of english versions of changgan xing. International journal of comparative literature \& translation studies, 6 (1).

Kennedy, X.J. (1983). Literature. An Introduction to Fiction, Poetry, Drama.Boston. Little, Brown and Company.

Khrisna, D.A.N, Djatmika, M. R. Nababan, Riyadi Santosa. (2018). Depicting the character of Santiago in the novel the old man and the sea from the systemic. Functional Linguistics Perspective. https://doi.org/10.20961/pras.v0i0.32020.g21412

Koesnosoebroto, S.B. (1988). Panduan pengajar buku the anatomy of prose fiction/Sunaryono Basuki Koesnosoebroto. Jakarta. Depdikbud.

Li, X. (2016). An attitudinal analysis of english song discourse from the perspective of appraisal theory. Journal of language teaching and research, 7(3), 559-565.

Li, Y and Gao, Y. (2013). An attitude study on the conflict between mother and her daughter-in-law in the novel double-sided adhesive from appraisal theory perspective. Journal of language teaching and research, 3(10), 1784-1789. https://doi.org/10.4304/tpls.3.10.1784-1789

Luciano Vitacolonna. (1977). Text structures, action description, and symbolic meanings of Hemingway's the old man and the sea. https://www.academia.edu/33810580/text structures action description and sym bolic meanings of hemingways the old man and the sea 


\section{BLTALL (ENGLISH LANGUAGE 'TEACHING, APPLIEI) LINGUISTIICS}

ANI) II'TIRA'TURE)

Vol. 1 No. 2, 2020

Available online at https://jurnal.iainponorogo.ac.id/index.php/eltall

Macken-horarik, M. (2003). Appraisal and the special instructiveness of narrative. 23(2), 285-312.

Martin, J. R., \& White, P. R. R. (2005). The language of evaluation. Palgrave Macmillan.

The, H. S., Man, O. L. D., \& Sea, T. H. E. (1977). Text structures, action description, and symbolic meanings of hemingway's the old man and the sea, p. 227-235. 